This item was submitted to Loughborough's Research Repository by the author.

Items in Figshare are protected by copyright, with all rights reserved, unless otherwise indicated.

Revisiting the red light district: still neglected, immoral and marginal?

PLEASE CITE THE PUBLISHED VERSION

PUBLISHER

(C) Elsevier

VERSION

AM (Accepted Manuscript)

LICENCE

CC BY-NC-ND 4.0

REPOSITORY RECORD

Hubbard, Phil, and Mary Whowell. 2019. "Revisiting the Red Light District: Still Neglected, Immoral and Marginal?”. figshare. https://hdl.handle.net/2134/4406. 
This item was submitted to Loughborough's Institutional Repository (https://dspace.lboro.ac.uk/) by the author and is made available under the following Creative Commons Licence conditions.

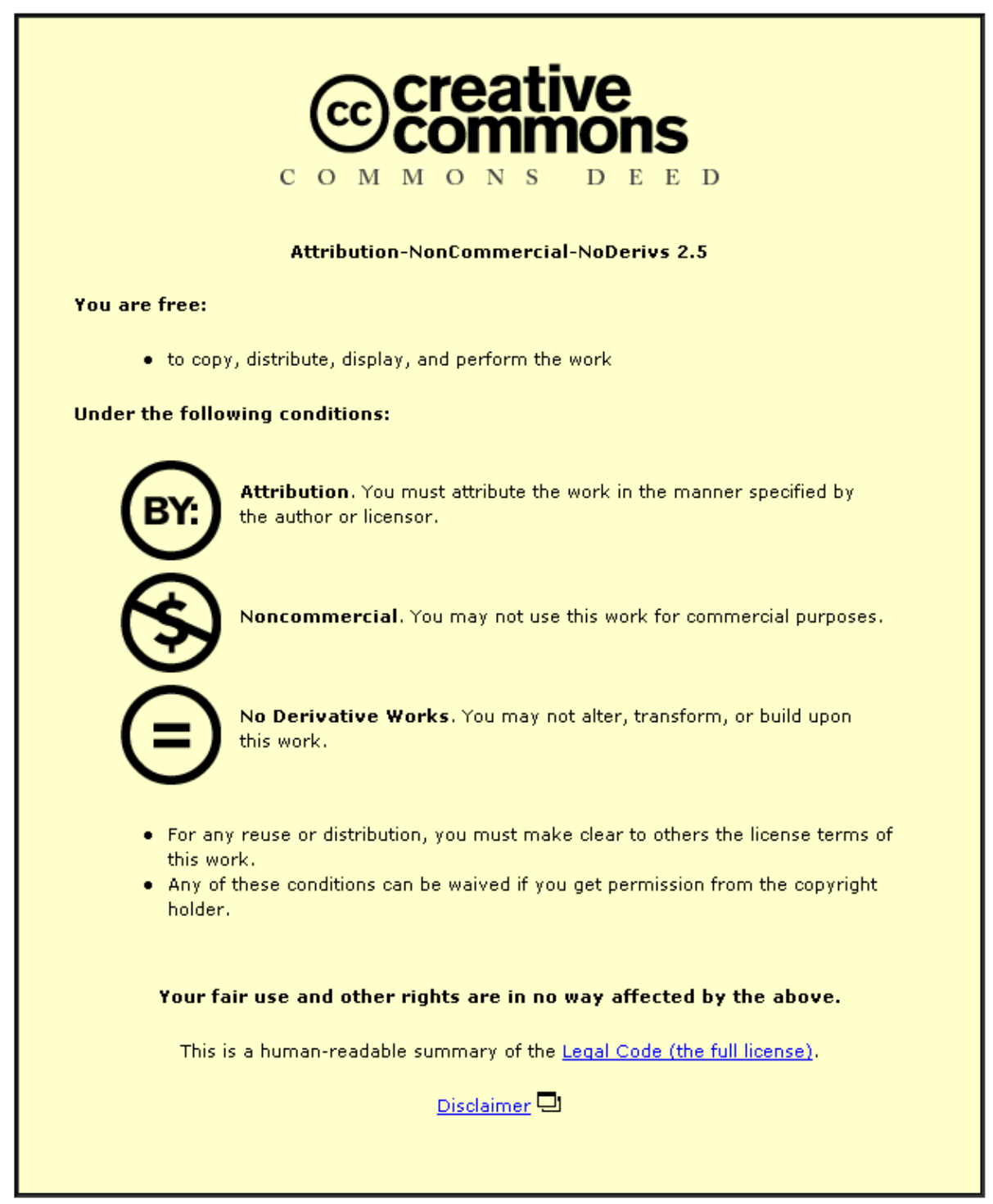

For the full text of this licence, please go to: http://creativecommons.org/licenses/by-nc-nd/2.5/ 


\title{
Revisiting the red light district: still neglected, immoral and marginal?
}

\author{
Phil Hubbard and Mary Whowell
}

\begin{abstract}
Twenty years ago, Ashworth et al (1988) offered a distinctive and innovative interpretation of a neglected aspect of the urban scene: the red-light district. Focusing on the location of female prostitution in a series of Western European cities, their paper suggested that the geographies of sex work are revealing of some of the 'less obvious' social and political processes that shape urban space. Here, we revisit Ashworth et al's paper in the light of subsequent developments in the organisation of commercial sex as well as the study of sexuality and space. Noting important continuities as well as major shifts in the location of sex work, with a significant shift to off-street forms of sex working having occurred, this paper argues that some of the ideas in Ashworth et al's paper remain highly pertinent, but others appear in need of updating. In particular, we stress the importance of focusing on men as both clients and workers within the sex industry, and flag up a number of connections that might be made with the emerging literatures on the geographies of sex itself. We hence conclude by considering Ashworth et al's paper as an important early intervention in debates surrounding the relations of sexuality and space, albeit one in which questions of gender, embodiment, and sexual desire remained largely unexplored.
\end{abstract}

KEYWORDS: urban geography, sexuality, regulation, gender, prostitution, EU

\section{INTRODUCTION}

In 1988, Geoforum published a paper by Greg Ashworth, Paul White and Hillary Winchester focusing on landscapes of street prostitution in Western European cities. At the time, they were able to claim that the geographical dimensions of such landscapes had 'very largely' escaped the attention of geographers, and 
that this neglect was 'unfortunate' given red-light districts are a familiar aspect of 'virtually all cities throughout the world' (Ashworth et al, 1988, 210). Though not the first consideration of prostitution by geographers (e.g. Rubin. 1975, Symanski, 1974; 1981), this paper was unique both as a consideration of the location of sex work in cities across Western Europe as well as an attempt situate its geographical study in a richer theoretical context. In the context of a discipline yet to be significantly buffeted by the 'cultural turn', post-modern praxis or queer theory, the paper sought to explain the geography of sex work primarily in terms of neo-classical theories of supply and demand, considering the importance of agglomeration economies and client access in creating notable clusters of street prostitution. Yet at the same time, it presaged emerging themes in the discipline by highlighting the influence of surveillance and social control in creating 'zones of tolerance'. Issues of social and cultural exclusion (also discussed in White and Winchester's, 1988, timely consideration of geographies of marginalisation) were hence prominent, with the balance between 'accessibility, opportunity and constraint ' seen to create 'immoral landscapes' in which this 'highly marginalised activity' could flourish (Ashworth et al 1988, 211).

In retrospect, what is perhaps most interesting about Ashworth et al's paper is its failure to explore how questions of sex and gender inform the production of redlight landscapes, with only cursory mention made of the way that female sex work may be organised by men to facilitate their access to women's bodies whilst still condemning women's participation in the sex industry (Duncan, 1996). Of equal significance, perhaps, is their failure to consider the landscapes and spaces associated with male (and trans) sex work. Yet this ignorance of questions of (hetero)sexuality, masculinity and commodification was not surprising in a discipline where feminist geography was, by and large, still fixated with gendered divisions of labour rather than gender relations per se, and where geographical explorations of sexuality had been restricted to isolated studies of gay and lesbian residence (e.g. McNee, 1984, Lauria and Knopp, 1985). Indeed, the underwhelming response to the paper at the time (evidenced in a distinct lack 
of citations) is indicative of a discipline that was either unable or unwilling to acknowledge the importance of sexuality as a fundamental locus of identity. Subsequent to Ashworth et al's paper, much has changed, with geographers now acknowledged as providing valuable accounts of the role of space, place and landscape in the constitution of sexual subjectivities. Feeding off a diverse range of queer scholarship, geographical work on the relations of sexuality and space has accordingly moved beyond studies of 'gay and lesbian residence' to posit more fluid and complex connections between sexual identities, practices and spaces (see especially Browne et al, 2007). Nonetheless, the geography of commercial sex work remains an important theme within this literature (e.g. Del Casino and Hanna, 2003, Hart, 1995, Howell, 2004, Hubbard, 2004, Kuenkel, 2004, Koskela and Tani, 2005, Law, 1997, Legg 2005), making a significant contribution to debates about the sexualisation of space.

In this paper, we accordingly reconsider Ashworth et al's article in the light of subsequent studies, reading it as an early intervention in the literatures on sexuality and space. This will allow us to reflect on progress in the discipline more generally by considering how red light landscapes are currently being conceptualised, studied and mapped by geographers in ways that extend Ashworth et al's analysis. In so doing, we will necessarily engage with current theoretical debates on gentrification, consumption and neoliberalism, suggesting that these cast significant new light on the relationship between sex work and the city. Yet in this paper we also wish to re-engage with the substantive focus of Ashworth et al's $(1988,202)$ article by remapping the 'visible manifestations' of sex work in selected Western European cities. Noting a number of important changes in the place of sex work, we conclude that the locational model of urban prostitution areas offered by Ashworth et al (1988) cannot adequately account for the current diversity of sites where sex is sold by both men and women.

The current paper draws on a diverse range of recent research on spaces of sex work in Western European cities (e.g. Aalbers, 2005, Coulmont, 2007, Redoutay, 
2005, Ruhne, 2004, Svanstrom, 2005), including the authors' own individual and collaborative research (e.g. Hubbard, 1999; 2004, Pitcher et al, 2006, Whowell, 2006). In so doing, it responds to Ashworth et al's $(1988,211)$ call for 'examination of locational change over time' whilst significantly extending their summation of the processes that create distinctive landscapes of prostitution. The structure of this paper hence mirrors that of Ashworth et al, beginning by describing the forms of prostitution evident in those world cities most notorious as centres of sex commerce, before turning to consider the forms of sex work found beyond the metropolitan core. To begin with, however, it is necessary to consider the ways in which prostitution has changed since the 1980s in response to wider technological, social and legal transformations.

\section{THE TRANSFORMATION OF COMMERCIAL SEX}

Though prostitution has long existed in a multiplicity of forms, it has been widely asserted that in the latter years of the twentieth century it took on dramatic new forms and modalities as the sex industry itself diversified and became more accessible. New forms of sexual commerce based on physical and virtual exchange emerged in both West and non-West, attracting new workers and customers, with telephone sex, interactive TV channels, web cams and Internet chat rooms allowing sexual services to be purchased 'at a distance' (Bernstein, 2004, Weitzer, 2005). In Bernstein's $(2007,474)$ view, these technologies have helped remove the biggest obstacles to the buying and selling of sexual services: namely, shame and ignorance. Spending on sexual services has hence reached new levels, with the 'adult entertainment' sector becoming an important growth sector in consumer-based societies, especially online (Zook, 2004). Such diversification problematises any neat distinction between prostitution, adult entertainment and pornography, given all provide forms of sexual gratification for payment or payment in kind. It also stresses that the stigmatising term 'prostitute' may be unduly restrictive when we consider the diverse ways in which 'sex' is 
bought and sold in contemporary cities, with this including the forms of penetrative sex and masturbation that Ashworth et al (1988) consider alongside a highly diverse range of sexual acts, services and encounters. Consequently, although exotic dancers, strippers, pornographic artists and telephone sex operators would not identify as prostitutes, all can be conceptualised as workers in a differentiated sexual economy in which sex is bought and sold in a multiplicity of forms. The term 'sex worker' is accordingly more than a mere euphemism for a prostitute, and has become the preferred term for those arguing for employment rights within the sex industry (Cusick, 2006).

That said, most countries continue to define prostitution (in common law, if not in statute) as involving the purchase of physical sexual services such as vaginal, anal or oral sex. With a few exceptions (e.g. Sweden, which criminalised the purchase of sexual services in 2000), buying or selling such sexual services is not an offence. However, in most jurisdictions, an abolitionist stance prevails, with governments setting out their view that prostitution is morally undesirable, exploitative and potentially dangerous through laws which prohibit brothels, pimping, soliciting, or otherwise encouraging prostitution. In practical terms, this means it is often impossible to sell sex without a number of laws being broken, meaning that it is only legal in private premises when it is a consensual transaction between two adults and where there is no third party involved.

Exceptions include the Netherlands, Germany, New South Wales and Victoria (Australia) and Nevada (US) where state-licensed brothels allow women (and sometimes men) to sell sex (subject to workers having appropriate work permits and being subject to medical screening). Even so, licensing places considerable restriction on the location, visibility and opening hours of such premises (e.g. in Germany there are innumerable 'Restricted area decrees' which ban sex work in many neighbourhoods - see Ruhre 2004, while brothels are only allowed in Nevada in the less populous counties, away from major urban centres). As such, the state and law continues to have significant influence on the form and location of sex work, even if it rarely enacts the forms of disciplinary governance and 
intensive medical surveillance that were prominent in the nineteenth century 'regulationist' era (see Howell, 2004; Svanstrom, 2004).

This said, the last twenty years have witnessed significant debates surrounding the effectiveness of prostitution laws (see Outshoon, 2004), with critics continuing to argue that legislation is dated, being replete with moralising concepts which assume sex work is always exploitative and never a profession which would be freely chosen (Kilvington et al, 2001). To the contrary, sex worker advocates make a case that sexual services should be increasingly regarded as part of a normal service economy, and that participants in the sexual economy should not be regarded as sexually or morally deviant (Kulick, 2003). Discourses of sexual liberation may be significant here, contributing to the representation of sex-related businesses as recreational settings where consenting adults are free to purchase sexual services. Bernstein $(2004,112)$ persuasively develops this argument, suggesting that buying and selling sex is now fundamentally dissociated from the idea of 'emotional' exchange, and hence is easily incorporated within (male) understandings of legitimate consumption, 'play' and even work. As she contends, this means the act of purchasing sexual services is increasingly situated in 'a normalised field of commercial practices', with clients' search for erotic encounter only understandable in the context of tendencies towards 'plastic sexuality' (Giddens, 1991) and the emancipation of eroticism from 'love' (Bauman, 1998). For Bernstein (2004), this is reflected in the changing nature of the commercial sex transaction, with the search for 'quick release' having largely been replaced by a model in which clients mainly seek a form of sexual encounter which offers 'bounded authenticity' and in which sex itself may become incidental.

The idea that spaces of sex work are increasingly regarded by consumers as recreational settings is, in part, reflected in their acknowledged - and growing significance in urban entertainment economies (Chatterton and Hollands, 2002). Indeed, the soaring demand for pornography, strip clubs, lap-dancing, escorts, and sex tours is seen to draw affluent consumers towards cities, promoting both 
business and group tourism (especially 'stag' and 'hen' parties). Imbued with a new-found respectability, sex-related businesses have been re-dubbed sites of 'adult entertainment', and often deemed compatible with the cosmopolitan and 'continental' ambience essential for creating a vibrant 24-hour city centres.

Hausbeck and Brents $(2002,102)$ identify the proliferation of adult entertainment venues at the heart of many cities as one of the clearest manifestations of the transformation of the sex industries from a 'small, privately-owned, illegitimate and almost feudal set of businesses dependent on local sheriffs looking the other way' to a 'multi-billion dollar business dominated by corporations'. LiepeLevinson $(2002,22)$ likewise argues 'the sleazy nudie bar, hidden away in a municipal district of-ill repute' no longer epitomizes the 'cultural and geographical location' of adult entertainment, with commercial sex being increasingly centralised, both socially and spatially.

In the EU, these trends are arguably most evident in those Europe cities where mobile workers and consumers co-mingle, and where commercial sex is readily accessible to both the casual visitor and cognoscenti. For instance, districts at the heart of London (Soho), Amsterdam (Wallen), Paris (Pigalle), Prague (around Wenceslas Square), Madrid (Calle Montera) and Hamburg (Reeperbahn) enjoy internationally-mediated notoriety for sexual commerce, their reputation enhanced by the proliferation of guidebooks, brochures and (especially) web sites which provide guides to the red light landscapes' of these cities. Herein, the sexual possibilities of the metropolis are mapped out in sometimes bewildering detail: the Paris Sexy (2004) guide, for instance, trades on the city's 'extroverted nature' (Corbin, 1978, 205), offering fourteen chapters of advice as to where travellers may locate sex workers, SM dungeons, swinger's clubs, saunas, striptease, pornographic cinemas, cabaret and other 'spectacles de eroticisme'. Sometimes, this form of sexual advertising is officially sanctioned, with sex work identified as a potential marketing tool (or 'soft location' factor') in the global battle for jobs and investment. For instance, the Netherlands Board of Tourism 
and Convention identifies the Red Light District as a key 'quarter' of Amsterdam, urging a visit:

From brothels to sex shops to museums, the Red Light District leaves nothing to the imagination. It is very likely that you will have heard about this neighbourhood and to be frank, everything you will have heard is probably true, but to really put rumours to rest, you have got to check it out for yourself. The Rossebuurt, as the locals know it, is unlike any other place. Guaranteed. Certainly, the Red Light District that everyone knows about is the one where women, of all nationalities, parade their wares in red-fringed window parlours, many ready to offer more than a schoolboy peep-show in a private cabin.(http://www.amsterdam.info/red-light-district/ accessed June 2004)

Significantly, the same source recommends visitors locate the area's 'infamous' condom shop before commencing their trip, noting that taking photographs of working women is bad etiquette (Aalbers, 2005). At the other end of the spectrum, perhaps, are those online blogs and chat rooms where clients exchange information about the price and quality of sexual services available in different cities. While such sources contain some unpalatable descriptions of male 'conquest', they are deeply revealing of the racist sexual imaginaries that encourage sex tourists to search out 'Other' and 'exotic' bodies (O'ConnellDavidson and Taylor, 2004).

The visibility of commercial sex at the heart of those world cities most central to global flows of business and finance (i.e. the major 'decision making centres' of the global economy) is thus connected to their enrolment within an increasingly interconnected world city network of sex commerce (Sanchez, 2003). In this regard, it is notable that female migrants from less affluent countries constitute a significant proportion of the workers/clients to be found in the brothels, clubs, bars, discotheques, cabarets, peepshows, sex shops, parlours, saunas, hotels, 
pensions, flats, parks, and streets which act as sites of sexual-economic exchange. One significant trend here - at least in Western European countries has been an apparent increase in numbers of Eastern European sex workers, with the International Organization for Migration estimating in 2003 that 120,000 women from Eastern Europe entered the European Union to work in the sex industry, in addition to a steady flow from Africa (mostly West Africa), Asia (mostly Philippines and Thailand) and Latin America (the Dominican Republic and Brazil) (Hughes, 2003). While some doubt the veracity of these figures (see Phoenix, 2007), it is widely asserted that the number of migrant sex workers is superior to 'locals' in all member states of the EU - including the 2004 accession nations Evidence of this is also visible through the increased availability of 'safer sex working' information in different languages available to sex workers through local sex worker outreach agencies and via the Internet. This has provoked some antipathy from 'native' workers, as well as raising anxieties about trafficking, migration and the porosity of the nation-state. For example, some German proprietors have suggested that the influx of migrant sex workers has been bad for business due to workers driving down prices, and racist attitudes towards migrant sex workers are emerging within many local markets (see especially Berman, 2003).

This given, it appears that international migration and sex tourism have become more important dimensions of sex work than was the case when Ashworth et al (1988) explored the geographies of prostitution. When coupled with tendencies towards the mainstreaming and gentrification of sex work, the result is that many 'traditional red light districts' have changed beyond recognition. But this process of tranformation is not uncontested, and corporate sex venues are sometimes opposed by residents' groups, business consortia and local politicians on the basis that they create negative externalities, attract disorderly clientele and discourage other forms of investment. Nor have such venues totally supplanted less corporate and independent forms of sex work, which have seldom disappeared, merely been displaced (see Hubbard, 2004). As such, street sex 
work 'strolls', 'beats' or 'patches' remain characteristic features of major European cities, albeit often displaced from their traditional locations in the central city. This means that the geographies of sex work remain highly variegated, with questions of morality, legality, and access conspiring to create constantly changing patterns of sex working that demand to be mapped, interpreted and theorised.

\section{AREAS OF PROSTITUTION IN WESTERN EUROPEAN CITIES}

Ashworth et al's $(1988,202)$ justification for detailing the geographies of commercial sex in Paris and Amsterdam is unclear beyond the fact that both boast 'traditional red light districts'. Nonetheless, while they make token reference to spaces of street working in Rome, Madrid, Barcelona, Hamburg and London (as well as smaller towns including Arnhem and Groningen), these two case studies provide the springboard for much of their discussion, and it is for this reason that we revisit their mappings here.

\section{Commercial sex in central Paris}

Paris arguably gained its reputation as a centre for commercial sexuality in the nineteenth century, with 'the bright artificial light of Paris by night stimulating the fantasies that sprang from that milieu' (Corbin, 1978, 98). While this reputation perhaps exaggerates the contemporary scale of sex work in the city, central Paris has remained punctuated by a range of well-known areas notorious as spaces of elicit encounter, pornography and prostitution. Drawing predominantly on an uncited guide to Paris nightlife, Ashworth et al's $(1988,203)$ account highlights four key areas of sex commerce: Pigalle, offering a 'complete package' of tourist-oriented sex shops, peep shows and prostitution; an area in transition around Montparnasse to the south where sex shops are 'shabby and drugs are openly offered for sale'; an area around St Lazare station where the vast majority 
of street workers are from 'ethnic minorities', and Rue St Denis, stretching from Beaubourg to the Grand Boulevards, where upper story flats (hotel de passe) were used for prostitution and up to 85 women per time would solicit for custom. Ashworth et al admit that this is a far from exhaustive inventory, however, and note the presence of brothels in Goutte d'Or catering to 'North African immigrants' as well as massage parlours in the more affluent arrondissement to the west of the city centre. However, they neglect to mention the Bois de Boulogne, which was notorious at the time as a location where transvestite prostitutes serviced a mixed clientele (including some noteable French politicians).

The sites highlighted by Ashworth et al undoubtedly remain important in the imagined erotic topography of Paris, with Pigalle in particular remaining synonymous with 'gamey, sinful' pleasures (Husey, 2006), trading on the presence of the Moulin Rouge and the ghosts of Zola, Baudelaire and Flaubert. Nonetheless, the bus-loads of tourists disembarking every evening at Place Clichy are no longer offered the 'complete package' reported by Ashworth et al, with off-street and street prostitution now scarcely evident in Pigalle. Instead, 'rip off' adult cabarets predominating (Schlor, 1998, 38). Likewise, in Montparnasse street working has completely disappeared, and the numbers working around St Lazare dramatically diminished, with just a few older women remaining. Rue St Denis remains significant as the location of numerous sex shops and 'sex superstores' (Coulmont, 2007), but here too 'les traditonelles' (literally, 'traditional women') have reduced in number and are largely found towards the northern end away from Beaubourg. Pedestrianisation of the street in the 1980s, and the subsequent improvement of the second arrondissement under Mayor Boutault in the 1990s, means that the area is host to fewer low-rent hotel de passe, and is a more salubrious residential area than was once the case.

As such, Paris' traditional red light areas (or so-called 'hot' districts) are no longer significant areas of street work. Instead, the key sites of street working now are 
around the marechaux (ring road) particularly the sparsely populated areas around the old gates (portes) (see Figure One). La Porte Dauphine remains known as a key area for transsexual working and for men selling sex to men; to the north Porte St Ouen is known for younger Russian and Kossovan workers; Romanian women around Porte Cligancourt and, to the north east, Porte Villette is known for north African workers. Just outside the marechaux, the Bois de Boulogne remains significant as the haunt of Latin American transvestites, and is also a public sex environment of some notoriety. At Nation, Chinese women predominate, while to the east of the city centre, beyond Nation, the Bois de Vincennes remains a popular location for kerb-crawling, with women selling sex from easily identifiable white vans parked alongside the main avenues through the woods; the women here are often Eastern European, driven down by boyfriends or managers from the northern suburbs. Redoutey (2005, 39, authors' translation) hence describes a journey around the peripheral ring road as revealing a 'micro-geography of prostitution' where country of origin appears more significant than age or drug-use in creating distinctive territories or 'beats'.

Reflecting on these changing geographies, Redoutey (2005) discerns a long-term centrifugal process in which street work has been decanted to the margins of the central city. Several factors appear to be significant here, not least the reported influx of migrant workers that occurred in the 1990s, mostly from Eastern Europe and 'clearly in the hands of mafia-type prostitution rings' (Mathieu, 2004, 158). In a context where the media has tended to conflate trafficking and sex work (Berman, 2003), this heightened awareness of Albanian, Moldovian, Russian and Bulgarian women, 'often very young and very visible in the urban landscape', provoked an apparent public outcry (Mathieu, 2004, 159). Stories of French prostitutes being chased off the streets by foreign competitors' pimps fuelled this moral panic, being woven into a wider narrative in which perceived breaches of public order in Paris were mapped onto immigrant Others (Dikec, 2006). Weary of conflict between incoming and established workers, residents in several areas of the city began to collect evidence of the nuisances caused by soliciting; in some of 
the Eastern parts of the city, young Arab migrants took to the streets in an attempt to move prostitution out of their neighbourhoods. Responding, some politicians on the right began to argue for a return to 'enclosed' state brothels. Notably, Françoise de Panafieu, deputy for the Seventeenth arrondissement in Paris, led a high-profile campaign against street prostitution in 2002, while the leftist mayor of Paris, Bertrand Delanoe, proposed a plan to re-educate prostitutes to work in 'more acceptable' professions (Allwood, 2004).

The visibility of migrant workers on the streets also placed increasing pressure on the mouers (vice police) to intervene in street markets (despite soliciting and kerbcrawling being legal in France so long as no nuisance was caused or sexual exhibitionism evident). In this context, the inclusion of amendments relating to prostitution in Sarkozy's Interior Security Act (passed in February 2003) was the culmination of a series of attempts to restrict the visibility of sex work in Paris. This Act enacted over seventy-five major changes to the articles of the Code Pénal. including controversial new powers of imprisonment for aggressive begging, a fine of up to 30,000 Euros for swearing at the police, and a maximum of two months imprisonment for youths repeatedly loitering in public areas of flats. This Act made 'passive' soliciting an offence, with up to two months in jail for 'soliciting by any means, including dress, position or attitude.' Equally controversially, once arrested for soliciting, any foreign national can have their Temporary Residence Permit withdrawn, with a Provisional Authorisation of Stay for three months granted only if a prostitute denounces their 'procurer or pimp', moves to protected lodgings and takes up a new occupation. Ignoring important questions about the conditions under which women enter France and begin to work as prostitutes, Sarkozy's reforms assumed deportation would 'save' women from sexual coercion.

Sarkozy's reforms were publicly resisted by prostitute unions, ACT-UP Paris and the Green Party, with a significant protest outside the Senat in 2002. The leftwing media was also critical, with an impassioned Editorial in La Parisien arguing 
that the 'traditionelles' were as much a part of Paris as 'steak-frites, cheap red wine and Gauloises cigarettes', and needed to be protected rather than persecuted. Despite such opposition, the new law was introduced in 2003 , with 50 women arrested on the first night for passive soliciting and 1726 arrested, 569 fined and 126 deported in the twelve months following the passing of the Act. Over the same period, the Parisian vice police estimated the number of 'active' prostitutes declined from 1700 to less than 1000 (Allwood, 2004). While independent 'French' prostitutes were never the target of Sarkozy's reforms, the effective criminalisation of all street work has nonetheless impacted on all. Mathieu (2004) concludes the main outcome of the Sarkozy law has been to create a permanent state of anxiety on the streets and make working conditions less secure. Outreach workers who offer support to workers from their mobile van (Bus des Femmes) report that many workers do not carry condoms because they fear this will be used as evidence of active soliciting. Furthermore, while brothel work is technically illegal, there is also a fear that many prostitutes have left the street in order to conduct their business in indoor premises (such as bars, nightclubs, or private flats) where they are controlled by pimps. Indeed, the rising number of arrests for pimping - 700 in 2006 - is seen by many as direct evidence of the generally increased levels of pimping in the industry, with women more reliant on protection when they are working in less safe environments. Marie-Line Champin of Bus des Femmes (cited in Le Monde, 3 October 2005) argued 'They've moved off the main boulevards and into more secluded spots - the woods, garages, massage parlours. They may be $40 \%$ less visible, but there certainly aren't $40 \%$ fewer'. In 2007 , the head of the French organization for the protection of human rights (OCRTEH) also clamed that key impact of the law had been to relocate sex work from the centre to the margins, effectively 'hiding' sex work in woodlands, suburban squats, studios and saunas (cited in Le Monde, 3 April 2007). 


\section{Spaces of sex work in Amsterdam}

Alongside Hamburg, Amsterdam was identified by Ashworth et al (1988) as the sex capital of Western Europe. Little has changed in this respect, with Amsterdam's continuing reputation as a sex capital associated with the persistence of visible prostitution at the heart of the tourist city. This is partly the legacy of the 1911 law banning brothels in the Netherlands that encouraged women to set up businesses independently advertising their services by sitting behind their windows. Latterly, entrepreneurs and club owners established windows on a more commercial basis, with the co-location of windows, street working, sex shops and clubs creating a distinctly touristic 'red light area' along the Zeedijk and adjoining streets:

The red-light district resembles the modern open-air shopping mall in the US. Relatively clean streets, little crime, a neon atmosphere, and windows and windows of women to choose from - every size, shape, and color (though not in equal amounts). The red-light district seems designed to be a tourists' Mecca. The range of services for the leisure traveler includes sex clubs, sex shows, lingerie and S\&M clothing shops, condomeries, and a sprinkling of porno shops. But the character of Amsterdam's red-light district is different from most other sex tourist locations because it is centered in an historic district ... and surrounded by an old, wellestablished residential neighborhood (Wonders and Michalowski, 2001, 553)

The figure of three million tourist visits to the red light district per year is often cited in the media, with the area seen as a significant lure not just for the maleonly stag parties who arrive by low cost air travel, but also international business and conference travelers. However, the notion that the area is clean, commodified and safe for tourists has not always been dominant, with Ashworth et al (1988) noting the personal insecurity that was long-associated with it. 
However, from the late 1980s onwards, police 'sweeps' gradually removed the drug-dealers whose consumer base largely consisted of addicted street workers and unwary tourists (Verbraek, 1990), encouraging the displacement of street working beyond the city centre. Given problems of drug-dealing and anti-sociality persisted in these areas, the City Council established a toleration zone as the most effective way of managing street working. As Visser (1998) describes, the Amsterdam tippelzone (literally, strolling zone) was established in 1996 in the docks area behind the Central Station: subject to constant police supervision, the zone included a 'living room' staffed by social workers providing health advice, support and counselling.

The patterns of street prostitution mapped by Ashworth et al (1988) in central Amsterdam have thus changed considerably, with a marked decline in street working in the city centre allowing the authorities to focus more explicitly on offstreet working. Indeed, Amsterdam developed policies for sex establishments in the 1990s, closing down those that failed to meet fire and safety regulations, and regularly checking for underage or illegal migrant working. Brothels with 'some semblance of decency' were permitted, even though they remained technical illegal under the 1911 law (Brants, 1998, 623). By the late 1990s, this form of 'regulated tolerance' had, however, became subject to considerable debate in the Netherlands, with allegations the police in fact ignored 'traffic nuisance....shouting in the streets, clients who urinated in people's doorways, a generally threatening atmosphere, much criminal activity of drug addicts and pimps, and frequent muggings of clients' (Wagenaar, 2006, 14). As in Paris, the increasing visibility of non-EU nationals in the sex work markets of Amsterdam was also a major spur to legislative reform (Outshoorn, 2004). According to the Justice Ministry, changes to prostitution legislation were hence desirable to regulate operations within the prostitution sector; to intensify the fight against forced prostitution; to protect minors from sexual abuse; and, above all else, reduce prostitution by 'illegal aliens'. The general ban on brothels was accordingly lifted on 1 October 2000 , allowing the licensing of brothels where these did not 'interfere with or 
disrupt public life'. All licensees need to demonstrate there is no forced sex work on the premise, that no worker will have to consent to sex without a condom and that no alcohol or drugs are permitted.

Since 2000, legal reform has had major impacts on Amsterdam's indoor sector, with licenses having been revoked for brothel owners employing illegal migrants, for money laundering or failing to declare earnings. The 2006 Bibob law in fact allows the local state to employ forensic accountancy procedures to trace payments made to brothel owners before 2000 , when brothel running was effectively illegal. This has allowed the Amsterdam Centrum authority to revoke the licenses of over one third of those businesses initially granted a license, leading the international media to speculate that Amsterdam's red light district is being effectively closed down (e.g. 'Amsterdam closes a window on its red light trade' The Observer, Sept 23 2007; 'Amsterdam to curb red light district' National Post Dec 18, 2007). Nonetheless, as of 2007, the city boasted a total of 130 brothels (equating to 350 windows with prostitutes seated behind them), 57 sex video shops and 16 closed sex clubs. The majority of these are in the Zeedijk/Wallen though there is a smaller red light district (Singel) which caters less for tourists and is altogether more subdued (see Figure Two). Licensing officials will now not renew licenses for brothels outside these areas, and are refusing to issue any new licenses for sex or prostitution establishments in general. Further, the city has refused to renew existing licenses where it is deemed premises are having a 'serious impact on local lives', or where their location is in conflict with the local development plan (e.g. licenses were refused in northern parts of Zeedijk identified as solely residential).

The overall conclusion about the introduction of legal brothels and a standardized licensing system is that it has allowed the city (as opposed to the police) to exercise more control over the regulated sector. The repeal of the brothel ban has also had important ramifications for street work: with the licensing of brothels, the authorities deemed there was no need for street working, with 
Amsterdam's Mayor Job Cohen suggesting it had in any case been 'impossible to create a safe and controllable zone for women that was not open to abuse by organised crime' (cited in Het Parool, 6 August 2003) Amsterdam's tipplezone finally closed in December 2003, meaning there is now nowhere for sex workers to solicit legally in Amsterdam. Given there were between 8000-10000 sex workers in Amsterdam before the repeal of the brothel laws, but only 1500 or so now work in licensed brothels and clubs, it is assumed there has been growth in off-street work in unregulated bordels, flats and cellars, mainly well away from a city centre. Yet perhaps the main impact of the legal reform has been to send out a message to potential clients that Amsterdam is a safe 'legal' space for sexual recreation. When coupled with the city's reputation as tolerant of soft drug use, it is perhaps not surprising that the streets of the red light area throng with crowds of tourists and voyeurs at weekends, with stag parties from the UK and other group tourists far outnumbering the solitary clients who are the 'regular' clients. It is these groups of (often rowdy) tourists who are argued to be diminishing the other 'more desirable aspects of the city's aspirations'; and increasingly seen as an obstacle to marketing Amsterdam as an attractive destination to other holidaymakers (Kavaratzis and Ashworth, 2007, 18). Rather than being an attempt to 'close' the red light district, the withdrawal of licenses for some widows - and the compulsory purchase of others - can be seen as a response to this demand for more upscale tourism, meaning that brothels increasingly co-exist with designer clothes shops and restaurants - and not just sex shops (see 'Amsterdam tries upscale fix for red light district crime', New York Times, 24 Feb 2008).

\section{Suburbanising sex work}

The examples of Amsterdam and Paris suggest that although off-street premises remain clustered in some of the areas identified by Ashworth et al (1988), the location of street working is changing in quite significant ways, with street 
prostitution being increasingly pushed out of valued city centre locations towards more marginal sites beyond the centre. These trends appear to have been mirrored elsewhere, with, for example, street prostitution now removed from Cologne's city centre (Kuenkel, 2007), street working disappearing in central Oslo, Stockholm and Copenhagen (Skilbrei, 2001, Svanstrom and Holgersson, 2007) and the gradual gentrification of el Raval (Barcelona) displacing street prostitution from the 'barrio chino' (Degan, 2003). Often, such shifts have been the result of premeditated policies of zoning, as has been the case with the Dutch tippelzones or the establishment of 'garagespaces' on industrial parks in Dortmund and Cologne.

This is also the case in the UK, where there have been a number of attempts to steer street sex workers into 'tolerance zones' or 'managed spaces', which are usually located on the margins of cities (Campbell and Van Doorninck, 2006). In Preston, a 'managed zone' allows sex workers to work at designated times without fear of arrest so long as they follow certain codes of behaviour. Likewise, in Northampton those working at night in some industrial areas are not prosecuted for solicitation (Bellis et al, 2007; Matthews, 2005). In Manchester, male and female sex workers access support around sexual health, drug-use, police liaison and wellbeing from outreach workers who patrol the unofficial 'tolerance zones'. However, it is Liverpool that is best known for pursuing an overt policy of zoning (Bellis et al, 2007). The city has a long history of prostitution, and the spaces in which women have plied their trade have changed markedly over the years. The proposed zone followed the tragic discovery of two murdered sex workers in July 2003, with research establishing that sex workers, residents and businesses were all largely in favour of the plans, despite disputes over its physical location (Bellis et al, 2007). Studies have shown that although there are inevitably problems associated with zones, they can result in significant decreases in violent assault and murder, and spark increases in the uptake of health based services (Campbell and Van Doorninck, 2006). However, against advice from many working in the field, managed zones for sex workers have 
officially been rejected by the Home Office $(2006,51)$, whose Coordinated Prostitution Policy asserts there is no place for street work in 'civilised societies'.

Despite the Home Office's stated policy, the police seem to tolerate street prostitution in British cities so long as it takes place away from residential or prime commercial sites (Matthews, 2005), implying a moral geography in which sex work is considered as a potential contaminant and source of property blight, properly located away from 'family' areas (Hubbard, 1999). At the same time as street work has been decentralising, licensing and planning policy in the UK has mirrored that noted in Amsterdam and Paris (above) by seeking a more equal balance between residential, business and off-street sex commerce within traditional city centre red light districts, encouraging better-managed and more upscale venues and generally reducing the density of sex establishments (see Hubbard, 2004, on the regulation of sex work in London's West End). Such tendencies resonate with recent debates in urban geography concerning the purification and corporatisation of city centre spaces through strategies of zero tolerance policing which serve to exclude abject Others (McLeod and Ward, 2003). Indeed, in an era when city governors, retailers and property investors appear especially keen to attract affluent consumers to city centre spaces, the Comment [MW1]: Changed this as consortia is repeated 3 lines down presence of street workers seems particularly troubling for those town centre managers, retail consortia and planners who are charged with sanitising the city in favour of 'family-oriented' consumption. On the other hand, the importance of marketing the city to the 'creative classes' means that the sexual freedom and diversity of the city can often be a key selling point: as Florida's (2001) influential account suggests, creatives are often drawn to cities with a reputation as 'edgy' centres of sexual excess, and, conversely, are repelled by boring, staid and conservative cities.

This type of reading suggests that policy-makers, far from trying to eradicate commercial sex, are seeking to render it more palatable and less 'sleazy' by encouraging corporate venues that can be marketed as part of a diverse 
package of urban entertainment (Chatterton and Hollands, 2003). The corporatisation of sex venues, coupled with the gentrification of red light districts, thus speaks of an urban neoliberalism which commodifies particular sexualities, and marginalises others (Bassi, 2006). As is the case with the selective commodification of gay identities, and the conscious creation of gay quarters by policy-makers determined to assert their credentials as a 'buzzing' metropolis, this raises important questions about the forms of sexual conduct that can be condoned by the state and law, and the way that contemporary urban policy privileges particular masculine desires (Nast, 2001). The consequences of this for sex workers themselves are yet to be fully documented, but are thought to be highly ambivalent. On the one hand, women sex workers are being given opportunities to work in legitimate premises that offer relatively secure working environments; on the other, women often pay to work in such premises, and may surrender much autonomy in the process (Sanchez, 2003). Further, the alternatives to corporate and organised sex work are becoming more precarious in the face of legislative reform and revanchist policing, with independent female sex work becoming increasingly marginal to the sexual economies of the central city (Hubbard, 2004).

Given the demand for commercial sex shows little sign of decline, the displacement of many forms of prostitution, as well as the general decline in street work, suggests a significant amount of off-street sex work is being carried out beyond the centre. Here, it should be noted that escort work is now probably the most important form of sex work practiced in European cities, with women (and men) offering outcalls (and sometimes in-calls) working from their own home. The importance of this sector has increased significantly in recent years, and though Ashworth et al (1988) comment on the use of newspaper advertising, the rise of mobile telephony and Internet sites advertising sexual services means that there are now many more opportunities for advertising prostitution. One symptom was the massive rise in phone cards in London telephone boxes over the 1990s: as police 'cracked down' on soliciting and kerb-crawling, independent 
workers realised they could advertise to potential clients at relatively low cost and at little risk by paying 'carders' to put their cards in public telephone boxes. While the authorities have been troubled both by the images on some of the cards, as well as the littering created, attempts to bar calls to advertised phone numbers have largely failed because of the unwillingness of some mobile operators to prevent their lines being used for what is, after all, a legal and private transaction (Hubbard, 2002).

Suburban massage parlours have hence flourished in many cities, with the Internet allowing clients to identify premises located within and beyond the city limits. 'Field reports' of commercial sex encounters, detailing what services are available, the quality of the service and the geographical location of the parlour or escort, have become widespread through Internet networking sites such as Punternet and Captain 69. Locally based providers such as Manchester's Little Black Book provide mini reviews and addresses for saunas and parlours in individual cities. Although some of the reports posted on websites have been argued to be offensive, reinforcing negative racial and gender stereotypes (Dickson, 2004), others can provide knowledge about those who buy and sell commercial sex, illustrating their varied social backgrounds and reasons for buying sex (Soothill and Sanders, 2005). Additionally, clients are encouraged to report cases of exploitation through websites, and, in some ways, could be classed as informal regulators of sex-related businesses.

In 1988, Ashworth et al argued that 'dispersed prostitution' in the form of saunas, massage parlours, or 'call girl' services have 'none of the environmental externalities of the traditional red-light district and, being less visible, give less offence and are less vulnerable to police action' (1988, 208-209). This interpretation largely holds true, with the police and authorities appearing relatively unconcerned about the sex being sold in the massage parlours and saunas that can now be found in nearly every UK suburban high street (Matthews, 2005). One widely publicised report by Eaves Housing suggested 
that there were as many as 730 flats and massage parlours in London, and 164 escort agencies, with prostitution occurring in every London borough and an average of 19 premises per borough (Dickson, 2004). Such premises only arouse concern when rumours of underage or illegal migrant working are widespread, in which case the police may visit and then report the premise to the local authority who enforce closure. Aside from this, in most parts of the UK little has been done to tackle off-street prostitution, although the Home Office are currently looking into the registration and legalisation of 'mini-brothels' on the unproven assumption that working indoors is safer than working outdoors. The complexity of both indoor and outdoor markets hinders generalisation about the safety of working men and women in different commercial sexualised spaces (Campbell and van Doornick, 2006). Hence, in a context where street prostitution is increasingly surveyed and managed because it is seen as socially undesirable and politically problematic, turning a 'blind eye' to less visible and peripheral establishments may lead to serious underestimates of the type and amount of sexual commerce occurring in particular contexts (something that has major consequences for the funding of services supporting sex workers).

\section{WHAT ABOUT THE MEN?}

While revisiting the mappings of prostitution offered by Ashworth et al (1988) allows some tentative conclusions to be drawn about the changing spatialities of commercial sex, it needs to be stressed that their mappings appear to relate only to female workers selling to male clients, with the possibilities of more varied subject positions is ignored. In the light of subsequent developments in the discipline, not least the impact of queer theory, the lack of acknowledgement that there are spaces where sex is sold by men to other men, and sometimes to women, is problematic. Indeed, the preoccupation of many urban writers with female prostitution - to the exclusion of other forms of sex work - has lead some commentators to suggest that this reflects patriarchal antinomies of desire and 
disgust in which the female streetwalker becomes a focus of both sexual and scholarly interest (Listerborn, 2006). Setting this argument to one side, Ashworth et al's (1988) failure to explore the geographies of male working can also be explained with reference to the lack of reputable studies that existed at that time: subsequently, however, male sex working is both better understood and more widely-documented. Indeed, reports from a variety of nations indicate that male and trans sex workers operate in a multiplicity of spaces, characterised by different modes of working.. These include streets and public sex environments (PSE), in bars and clubs, from sex parties and brothels, from home and via outcalls, and in saunas. Men also work as pornographic artists in films and photo shoots, as strippers, exotic dancers and as erotic masseuses (see Connell and Hart, 2002; Gaffney, 2002; Parsons et al, 2007 Smith, 2002; Thomas, 2000). In recent years, the Internet has played an increasingly large role in the promotion of male commercial sexuality, with the emergence of networking websites such as Gaydar integrating the possibilities of anonymous sex with commercial sexual encounters.

Research suggests that sexual exchanges are performed by workers differently across these different spaces. In. PSEs, fpr example, sex work has the potential to operate more opportunistically, as it is already a space of sexual experimentation for many men and offers the possibility of a somewhat cushioned introduction to sex work (Gaffney, 2002). Against this, independent workers may have to organise their time and lifestyles so that they are able to respond to client calls or bookings or at any time of day or night (Gaffney, 2002). In competitive markets where there are many workers catering to local clienteles, attracting and maintaining a regular clientele may also depend on workers' ability to 'perform' particular sexual identities. For example, in Manchester it has been noted that street workers dress in a certain way to attract clients; may give a potential punter 'a nod' whilst being in the right space at the right time - a tactic that can be crucial to business (Whowell, 2008). 
Although much research has been completed on the sexual health of male and trans sex work (see Aggleton, 1999 and Bimbi, 2007 for an overview), perhaps one of the most pressing issues for male and trans sex workers and those working with them is their invisibility within policy. In England and Wales, for example, men are essentially written out of policy as there is no substantive analysis of male and trans sex work within the current national Coordinated Prostitution Strategy (Home Office, 2006).. This invisibility in policy is problematic especially when juxtaposed with the increasing visibility of the men as workers in the sex industry and it is clear that men of all nationalities, ages and sexualities sell sex. The gender bias in policy (also encouraged by the double stigma of prostitution and homosexuality in some cultures) is reflected in wider discourses in prostitution policy which depict men as potential child abusers, exploiters of women, or antisocial kerb-crawlers - and never as professional and respectful sex workers (or clients). This misconception insinuates that men and boys have little or no need for support services - an assumption that is unproven theoretically or practically. Such assumptions also falsely suggest that men and boys are always able to 'stand up for themselves', never fall victim to male or female abusers; or, conversely, are unable to create and maintain amicable and, in some cases, intimate relationships with clients (Sanders, 2005).

Hence, although there are stories of men who have had negative experiences working in the sex industry (West and de Villers, 1992) or have been made famous through their sex work (such as Aiden Shaw) the majority of men (as the majority of women) working in the sex industry fall somewhere in the middle:

[They are] 'normal' men who make a choice to sell sex. Most do it for a short period, most work off street and most would not consider themselves as victims or as having been abused' (Gaffney, 2007, 28).

This implies that the different and varied subject positions of sex workers should be acknowledged in both policy and research. Underlining this, Hall's (2007) 
study of men who sell sex to men in Prague, typically in the 'major encounter' points where Slovaks, Czechs and Western tourists mix, suggests that many men deny their involvement in prostitution, claiming that accepting payment in kind for sex (e.g. drinks, food, gifts) does not constitute sex work. Against this, other work suggests that there are many who regard sex work as a career and want advice around managing finances and providing a professional and soughtafter service (Parsons et al, 2007). Although these examples represent what could be considered opposite ends of the sex work spectrum,, the key point is that there is no such thing as a 'typical' sex worker.

Taken together, such evidence suggests that the expectations of sex workers and clients alike may be highly variegated and immanent in the encounter, shaped by the intersectionality of class, gender, age and ethnicity of both worker and client. In Amsterdam especially, recent evidence suggests that populations of street- and bar-based male workers negotiate sex according to their migrant status (illegal/legal) and ethnic background as much as their sexuality. AMOC, the only agency currently working with male sex workers in Amsterdam, make a distinction between 'Dutch guys, who can stand up for themselves...negotiate their clients, prices, can talk about STDs, Hepatitis and are professional' and 'immigrant workers (Romanians, Turks, Moroccans) who do not identify as gay' (interview conducted with agency worker, 2007). While the former may work the two well-known hustler bars, the latter will not enter these spaces (for fear of being labelled homosexual), working mainly around Reguliersdwars Straat and Rembrandt Square (where the former group also work). The suggestion here is that space shapes practices of sex work in significant ways, but that hierarchies of sex work do not always map onto space in predictable ways (see Hart, 1995).

\section{THE BODY AND SEX ITSELF}


On the basis of their case studies, Ashworth et al $(1988,208)$ conclude by offering a 'general model' of urban prostitution (see Figure Three). In essence, this model identifies three forms of clientele - local deprived, international wealthy and local wealthy - suggesting that each seek sex in particular locations, producing discrete 'sectors'. For poorer, local clientele, inner city areas of street prostitution were regarded as most important, while for more wealthy local clients contact with women in dispersed and discrete sites of sex working was regarded as most significant. For international clientele, most sex was thought to be purchased in areas of urban entertainment as part of a more general consumption of nightlife.

In seeking to explain why three distinctive landscapes of prostitution had emerged in Western cities, Ashworth et al $(1988,208)$ hence laid much emphasis on supply and demand, albeit that they considered the contingent influence of accessibility, opportunity and constraint. In retrospect, the weight given to neoclassical economic theories, and claims that buying sex is governed by the same principles of consumer choice as, for example, 'the purchase of a pair of shoes' downplays the influence of legal and social controls. In simple terms, while any act of consumption is potentially freighted with legal and ethical implications, buying a sexual service continues to raise the spectre of legal censure, moral condemnation and social disapproval in highly distinctive ways. Indeed - and notwithstanding the putative mainstreaming of 'pornoculture' (Bernstein, 2004) - the current demonisation of prostitutes' clients (Kulick, 2003) and the frequent conflation of prostitution, trafficking and child sexual exploitation in policy debates (Home Office, 2004), suggests that the purchase of sex remains socially problematic:

In an age of gender politics and political correctness, the cheeky married man who wants a cheap thrill from oral sex on the street is an easy target. He can legitimately be constructed as a threat to all innocent women and a hazard to creating "safe" communities. Yet the stereotype does not hold 
up to much assessment... Most men apprehended for kerb-crawling offences do not have criminal records, are in full-time employment and are upstanding members of the community and of families. Although in some markets sex workers experience violence, most commercial sex interactions happen without incident, condom use is high and sex workers complain more about intense policing and a lack of monitoring than about the clientele (Sanders, 2007, 18).

The implication here is that while clients are drawn from a wide spectrum of society - and hence no more likely to be violent or deviant than any other group - they are predominantly imagined as sexual Others, pathologised as sexually needy and socially abject. This means that men's purchasing of sex frequently remains covert, or is carried out in spaces-times away from their normal spaces of work and homelife (see Bernstein, 2007).

While there has been some exploration of the 'moral geographies' of prostitution (see Hubbard, 1999) the idea that spaces of sex work exist outside the 'normal' realms of home and work, and allow for the re-organisation and re-working of sexual norms, suggests that the affective geographies of these spaces could benefit from further scrutiny. Aside from passing reference to the outside appearance of premises in Paris and Amsterdam, Ashworth et al say little about the way in which the ambience of particular settings contributes to the consumer experience by heightening or arousing specific desires. Equally surprisingly, while Ashworth et al assert the need for sex workers to display themselves as 'for sale', little mention is made of the practices of sex work that produce red light landscapes (such as the ways that sex workers perform particular idealised identities to appeal to particular types of clientele, the negotiation of intimacy and the transaction of sex itself). This lacuna appears surprising in the light of the 'bodily turn' and the interest in performativity that has animated much subsequent social and cultural geography, though the lack of attention given to sex itself was perhaps not surprising in a discipline where issues of sexuality still aroused 
controversy and where geographers working in this area regularly had their work rejected or censored because of the way it focused on sexual issues rarely discussed in the discipline (see McNee, 1984; Bell, 1995). Indeed, Ashworth et al recount in personal correspondence that their paper had indeed been rejected by at least one editor (without being sent to review) because it was not suitable for publication in a mainstream geographical journal. In this context, discussing sexuality in terms of the disembodied categories of worker/client rather than considering the forms of sexual exchange played out in different spaces no doubt appeared a necessary compromise.

The elision of the body in the paper - and much subsequent geographical work on prostitution (though see work on the biopolitics of prostitution, e.g. Legg, 2004) - is disappointing given the spaces identified in this paper as spaces of sex work only become so through embodied performances which mark off bodies as for sale: this is not just about forms of dress/undress, but the repertoire of gestures and looks which reproduce sexual economies of desire in which the gaze remains paramount. Gregory's (2006) anthropological account of sex work in Amsterdam is of note here, as it documents the way that transsexual workers distinguish between potential clients and 'sightseers', adopting 'hyper-feminine' performances to compete with the (female-gendered) workers who monopolise the best windows along the main streets. There is also some insightful work which explores the way the paid-for encounter involves different forms of bodyworking in different contexts, with certain forms of touching, kissing and intercourse allowed between clients and workers in some contexts, but not in others (see Liepe Levinson, 2002; Oerton and Pheonix, 2001), Understandably the limits of ethical ethnographic research constrain the type of research which might be conducted on the conduct of sex work, thought interviews with workers and clients can be revealing of the negotiated 'rules of the game'. Focusing on the performances of sex working played out in different spaces will undoubtedly help us better understand how spaces become sexualised through practice, and take us beyond perspectives in which the body of the prostitute might be 
conceived as simply subject to social forces and incapable of resisting and reworking dominant gender and sexual norms. Further work on the different forms of bodily contact, touching and fucking negotiated in different spaces would also underline that sex work takes a multitude of forms, encompassing different gender, sex and class relations. There is not simply one geography of prostitution, but many overlapping geographies.

\section{CONCLUSION}

In technological, cultural and legal terms, much has changed since Ashworth et al (1988) mapped out the geographies of prostitution in Western Europe. The growth of the Internet as a means of buying and selling sex, the expansion of global sex businesses and the increased mobility of clients and workers are all significant in producing new opportunities for sexual commerce. In turn, such new sexual 'markets' have generated new anxieties about the erosion of sexual and social boundaries. The response of the state and law to such anxieties has included attempts to make a distinction between playful 'adult entertainment' and forms of prostitution that are considered exploitative, sleazy and dangerous (Hubbard, 2004). In practice, of course, these distinctions remain highly problematic. Nonetheless, new laws have been introduced across Europe in the interests of encouraging well-organised, discrete and corporate sex businesses and discouraging independent street work. The impacts of these laws are writ large in the urban landscape, and while it might be assumed the Dutch model of legalization, French abolitionism and Swedish prohibitionism would have very different geographic imprints, the evidence presented in this paper suggests that even when states adopt divergent policy positions, emerging urban geographies of sex work are also becoming remarkably similar across major European cities. Street work is certainly becoming less significant, with more and more sex sold off street in flats and massage parlours in either the licensed or unregulated sector. Of these, licensed spaces tend to be more centralised, visible and 
clustered than unregulated sites, which are more widely dispersed and suburbanised.

More than a simple mapping of sex work, Ashworth et al's (1988) paper persuasively suggested that geographies of prostitution are revealing of the wider processes 'determining' urban land use. Presaging concepts that were to later exercise considerable influence within the discipline, Ashworth et al described prostitution as a marginal social activity whose geographies are indicative of its place in social and spatial hierarchies. However, in stressing the determining role of economic and political power that resided with particular groups, they subscribed to an essentially class-based perspective in which lower-class street prostitution occurs in working class neighbourhoods and upper class prostitution in more affluent areas. By simplifying in this way, they hence offered only a partial insight into the production of red light landscapes, and perpetuated stereotyped ideas that working class men visit low-class streetwalkers while international businessmen use the services of 'high class hookers'. Moreover, their paper was remarkably de-sexed and un-erotic, ignoring the geographies of sex itself to present the client and prostitute as disembodied ciphers whose behaviours and motivations are assumed. However, we must remember that this is a reflection of what kind of geographical enquiry was perceived to be intellectually - and even morally - acceptable at the time. In effect, the generalised and abstract model of prostitution developed in the paper allowed the authors to present prostitution as a legitimate subject for enquiry, framed in terms of 'respectable' traditions of locational modelling, rather than potentially less acceptable (and publishable) geographies of sex.

In this paper we have therefore sought to both update and 'flesh out' Ashworth et al's (1988) analysis, drawing on a range of European studies to demonstrate that the interplay between society, sexuality and space is more complex than Ashworth et al suggested. The fact their model of urban prostitution is ultimately unable to account for the diverse range of female and (especially) male sex work 
markets that currently exists in European cities suggests that there is a need to consider more fully how changing technologies, practices and laws interact to constrain or enable particular gender/sex performances in particular places.

Additionally, it appears important to consider why the police, residents and local businesses have become more or less tolerant of sex work in particular communities - an issue that relates to concerns about anti-sociality and nuisance as well as property values and development potential. Despite failing to address such issues, we should note that Ashworth et al's account has proved highly resilient in other respects, with the emphasis placed on the socio-spatial marginalisation of sexual Others flagging up a series of issues that have been developed in subsequent research on the relations of sexuality and space (see Browne et al, 2007). Likewise, the idea that the location of sexualised spaces actually enhances the economic value of particular forms of sexual exchange is one that has been refined in subsequent discussions of the spaces of both gay (Brown, 2001; Bassi, 2005) and straight sex (Papayanis, 2000; Hubbard 2000; 2008). This given, the lack of citation of Ashworth's (1988) paper in later years is curious, suggesting that for many readers it was interpreted as being narrowly concerned with prostitution per se rather than the wider sexual and social orders of the city. Our hope is that our re-engagement with their paper, and our own attempt to map the geographies of sex work, has demonstrated that geographies of prostitution continue to strike at the heart of debates concerning both the production of urban space and the construction of sexual identities. 


\section{REFERENCES}

Aalbers, M.B. 2005. Big sister is watching you: gender interaction and the unwritten rules of the Amsterdam red-light district. Journal of Sex Research 42, 54-62.

Aggleton, P. 1999 (Ed.) Men who sell sex: International perspectives on male prostitution and HIVIAIDS Philadelphia: Temple University Press

Allwood, G. 2004. Prostitution policy in France. Contemporary Politics 10, 145157.

Ashworth, G., White, P. and Winchester, H.P.M. 1988. The red-light district in the West European city: a neglected aspect of the urban landscape. Geoforum 19, 201-212.

Bassi, C. 2006, Riding the dialectical wares of gay political economy: a story from Birmingham's commercial gay scene. Antipode 38, 213-35.

Bauman, Z. 1998, Liquid Modernities. Cambridge, Polity.

Bell, D. 1995 [Screw]ing geography (censor's version). Environment and Planning D - Society and Space 13, 127-131.

Bellis, M.A., Watson, F.L., Hughes, S., Cook, P.A., Downing, J., Clark, P. and Thomson, R. 2007, Comparative views of the public, businesses and residents on establishing managed zones for prostitution. Health and Place 13,603-616.

Benson, C., and Matthews, R. 1995. Street Prostitution: Ten Facts in Search of Policy. International Journal of the Sociology of Law, 23, 395-415

Berman, J. 2003. Unpopular strangers and crises unbound: discourses of sex trafficking and the panicked state of the modern state, European Journal of International Relations, 9, 37-86

Bernstein, E. 2004, Desire, demand and the commerce in sex. In: Bernstein, E. and Shaffner, L. (Eds.) Regulating Sex: The Regulation of Intimacy and Identity. New York, Routledge, pp. 101-128

Bernstein, E. 2007, Sex work for the middle classes. Sexualities, 10 pp. 473-488.

Bimbi, D.2007 Male prostitution: Pathology, paradigms and progress in research Journal of Homosexuality 53, 7-35

Binnie, J. and Skeggs, B. 2004, Cosmopolitan knowledge and the production and consumption of sexualised space: Manchester's gay village. The Sociological Review 52 39-61 
Brants, C. 1998, The fine art of regulated tolerance: prostitution in Amsterdam. Journal of Law and Society 25, 621-635.

Brents, B. and Hausbeck, K. 2007, Marketing sex: US legal brothels and late capitalist consumption, Sexualities 10, 425-437.

Brown, M. 2001 Closet space. London, Routledge.

Browne, K., Lim., J. and Brown, G. (eds) 2007, Geographies of sexualities: theory practices and politics. London, Ashgate.

Campbell, R and Van Doorninck M 2006, Zoning Street Sex Work: One Way Forward? In: Campbell, R. and ONeill, M. (Eds.) Sex Work Now Cullompton, Willan, pp. 62-91

Chatterton, P. and Hollands, R. 2003, Urban nightscapes: youth cultures, pleasure spaces and corporate power. London, Routledge.

Connell, J. and Hart, G. 2003 An overview of male sex work in Edinburgh and Glasgow: The male sex worker perspective Medical Research Council, Social and public Health Sciences Unit, Occasional Paper 8

Corbin, A. 1978, Filles de noce: Misère sexuelle et prostitution aux 19e et 20e siècles. Paris, Aubier Montaigne.

Coulmont, B. 2007, Sex shops: un historie francais. Paris, Editions Dilecta.

Cusick, L. 2006, Widening the harm reduction agenda: From drug use to sex work. International Journal of Drug Policy 17, 3-11,

Cusick, L. and Berney, L. 2005, Prioritising punitive responses over public health: Commentary on the Home Office consultation document 'Paying the Price.' Critical Social Policy 25, 596-606

Degen, M. 2003, Fighting for the global catwalk: formalizing public life in Castlefield (Manchester) and diluting public life in el Raval (Barcelona). International Journal of Urban and Regional Research 27, 867-880

Del Casino, V.J, Jr. and Hanna, S.P. 2003 Mapping identities, reading maps: the politics of representation in Bangkok's sex tourism industry. In Hanna, S.P. and V.J. Del Casino, Jr. Mapping Tourism. Minneapolis: University of Minnesota Press, 161-185.

Dickson, S. 2004, Sex in the city. London, Eaves Housing

Dikec, M. 2007, Badlands of the republic. Oxford, Blackwells

Doorninck, M. van 2004, Business Like Any Other? Managing the Sex Industry in the Netherlands. In: Thorbeck, S. and Pattaanaik, B. (Eds.) Transnational approaches to prostitution. London, Routledge, pp. 193-200.

Duncan, N. 1996, Renegotiating gender and sexuality in private and public space. In: Duncan, N. (Ed.) Bodyspace. London, Routledge, pp. 27-145

Florida, R. 2003, The rise of the creative class. New York, Basic Books

Gaffney, J. 2002, Guidelines for development of outreach work with men who sell 
sex. In Schiffer, K. (Ed.) Manual: Tips, tricks and models of good practice for service providers considering, planning or implementing services for male sex workers Amsterdam: European Network Male Prostitution, pp 8-30

Gaffney, J. 2007. A Co-ordinated prostitution strategy and response to paying the price - but what about the men? Community Safety Journal 6, 27-33

Giddens, A. 1991, The constitution of society. Cambridge, Polity Press

Gregory, K. 2005, The everyday life of sex workers in the Netherlands. London, Routledge.

Groom, TM and Nandwani, R. 2006. Characteristics of men who pay for sex: A UK sexual health clinic survey, Sexually Transmitted Infections, 82, 364-367

Hall, T. 2007, Forms of transactional sex in Prague among young men who have sex with men, Czech Sociological Review 43, 89-109.

Hart, A. 1995, (Re)constructing a Spanish Red-Light District: Prostitution, Space, and Power. In Bell, D. and Valentine, G. (Eds.) Mapping Desire: Geographies of Sexualities, London, Routledge, pp. 191-230.

Hausbeck, K., and Brents, B. 2002, McDonaldization of the sex industry? The Business of sex. In: Ritzer, G. (Ed.) McDonaldization: the reader, Thousand Oaks, CA, Pine Forge Press, pp. 91-107.

Howell, P. 2004, Race, Space and the Regulation of Prostitution in Colonial Hong Kong, Urban History 31, 229-248

Holgersson, C. and Svanström, Y. 2008, Sex clubs and escorts - on the consequences of sexual entertaining in organisations Gender, Work \& Organization special issue: Sexual spaces, forthcoming.

Home Office 2004, Paying the Price: a consultation paper on prostitution' London: Home Office

Home Office 2006, A Coordinated Prostitution strategy and a summary of responses to Paying the Price London, HMSO.

Hubbard, P. 1999 Sex and the city; geographies of prostitution in the urban West Chichester, Ashgate.

Hubbard, P. 2000, Desire/disgust: mapping the moral contours of heterosexuality. Progress in Human Geography 24, 191-217.

Hubbard, P. 2002, Maintaining family values? Cleansing the streets of sex advertising. Area 34, 353-360.

Hubbard, P. 2004, Revenge and injustice in the revanchist city: uncovering masculinist agendas. Antipode 36, 665-686.

Hubbard, P. 2008, Here, there, everywhere: the ubiquitous geographies of heterosex. Geography Compass, forthcoming.

Hussey, A. 2006, Last tango in Paris. The Independent, July 30, 18.

Kavaratzis, M. and Ashworth, G. 2007. Partners in coffeeshops, canals and 
commerce: Marketing the city of Amsterdam Cities 24, 16-25

Kilvington, L., Day, S. and Ward, H. 2001, Prostitution policy in Europe: a time of change? Feminist Review 47, 78-93.

Koskela, $\mathrm{H}$ and Tani, S. 2005, Sold out! Women's practices of resistance against prostitution related sexual harassment. Women's Studies International Forum 28, 418-429.

Kuenkel, J. 2004, Warum wir im Dunkeln, aber keine Arbit im schatten haben sollen: eine fallstudie zur Sexarbeit an der Kurfurstenstrabe in Berlin. In: Manning, $S$ and Mayer, M. (Eds.) Praktiken informelloer Oknoomie. Explorative studien in Berlin und nordamerikanischen Stadten, Berlin, 90-109

Kuenkel, J. 2007, Pretty girls' in 'hip neighborhoods': the rehierarchization of sex work in neoliberal cities. Paper presented at Association of American Geographers conference, San Francisco.

Kulick, D. 2003, Sex in the New Europe: The Criminalization of Clients and Swedish Fear of Penetration. Anthropological Theory 3, 199-218

Lauria, M. and Knopp, L. 1985, Toward an Analysis of the Role of Gay Communities in the Urban Rennaisance. Urban Geography 6, 152-169

Law, L 1997 Dancing on the Bar: Sex, Money and the Uneasy Politics of Third Space. in Pile, S. and Keith, M. Geographies of Resistance, London: Routledge pp. 107-123

Legg, S. 2004 Foucault's Population Geographies: Classifications, Biopolitics and Governmental Spaces. Population, Space and Place 11, 137-156

Lever, J., and Dolnick, D. 2000, Clients and Call Girls: Seeking Sex and Intimacy. In R. Weitzer (Ed.), Sex for Sale,. London, Routledge, 85-100

Leridon, H., van Zessen, G., and Hubert, M. 1998. The Europeans and their Sexual Partners. In: Hubert, M., Bajos, N. and Sandfort, T. (Eds.) Sexual behaviour and HIVIAIDS in Europe, London UCL Press, 23-45

Liepe-Levinson, K. 2002, Strip show: Performances of gender and desire. New York, Routledge.

Listerborn, C. 2003, Prostitution as 'Urban Radical Chic'? A Note on the Silent Acceptance of Female Exploitation. City 7, 237-245.

Lowman, J. 1992 Street Prostitution Control: Some Canadian Reflections on the Finsbury Park Experience. British Journal of Criminology 32, 1-17,.

MacLeod, G. and Ward, K. 2002, Spaces of utopia and dystopia: landscaping the contemporary city. Geografiska Annaler: Series B, Human Geography 84, 15370.

Mckeganey, N. and Barnard, M. (1996) Sex work on the streets: Prostitutes and their clients. Buckingham, Open University Press

McNee, R. 1984, If you are squeamish. East Lakes Geographer 19, 16-27. 
Mathieu, L. 2004, The debate on prostitution in France: a conflict between abolitionism, regulation and prohibition. Journal of Contemporary European Studies 12, 153-164.

Matthews, R. 2005, Policing prostitution ten years on. British Journal of Criminology 45, 1-20.

Nast, H. 2002, Queer patriarchies, queer racisms, international. Antipode 34, 874-909.

O'Connell Davidson, J. and Taylor, J.S. 2004, Travel and taboo. In: Bernstein, E. and Shaffner, L. (Eds.) Regulating Sex: The Regulation of Intimacy and Identity. New York, Routledge, pp. 101-128.

Oerton, S. and Phoenix, J. 2001 Sex/bodywork: discourses and practices Sexualities 4, 387, 412.

Outshoorn, J. 2004, Pragmatism in the Polder: changing prostitution policy in the Netherlands. Journal of Contemporary European Studies 12, 165-176.

Parsons, J.T. Koken, J.A. and Bimbi, D.S. 2007 Looking beyond HIV: Eliciting individual and community needs of male internet escorts Journal of Homosexuality 53, 219-240

Papayanis, M. 2000, Sex and the revanchist city: zoning out pornography in New York. Environment and Planning D - Society and Space 18, 341-354.

Phoenix, J. 2000 Sex Traffic: Prostitution, Crime and Exploitation Human Traffic and Transnational Crime: Eurasian and American Perspectives. The British Journal of Criminology 47:515-517

Pitcher, J., Campbell, R., Hubbard, P., O'Neill, M. and Scoular, J. 2006, Living and Working in Areas of Street Sex Work: from conflict to coexistence. Bristol, Policy Press.

Redoutey, E. 2005, Trottoirs et territories. In: Handaman, E.H. and MossuzLavan, J. (Eds.) La prostitution a Paris Paris, Editions de la Martiniere, pp. 39-90.

Rubin, B 1975, Prostitution in Nevada. Annals of the Association of American Geographers 65, 113-120

Ruhne, R. 2005, Räumliche Kontrollformen der Prostitution und die, Ordnung der Geschlechter. Sic! Forum für Feministische Gangarten (März S) 12-15.

Ryder, A. 2004, Adult entertainment spaces: between a rock and a hard place or going from strength to strength? Urban Studies 41, 1659-1686.

Sanchez, L. 2003, Sex and space in the global city. In: Warren Perry, R. and Maurier, B. (Eds.) Globalization under construction, Minnesota: University of Minneapolis Press, pp. 151-178.

Sanders, T. 2004, The risks of street prostitution: punters, police and protesters Urban Studies 41, 1703-1717.

Sanders, T. 2005 Sex Work: A risky business Devon: Willan Publishing. 
Sanders, T. 2006. What we Know about men who buy sex. Paper given at UKNSWP annual conference 'Working Within and Challenging: Critical Reflections on the National Strategies? $6^{\text {th }}$ October.

Sanders, T. 2007, No Room for a Regulated Market?: The Implications of the 'Coordinated Prostitution Strategy' for the Indoor Sex Industries. Community Safety Journal 6, 34-44.

Schlor, J. 1998, Nights in the big city. London, Reaktion.

Skilbrei, M. 2001, The Rise and Fall of the Norwegian Massage Parlours:

Changes in the Norwegian Prostitution Setting in the 1990s. Feminist Review 67, 1-15.

Smith, C. 2002, Shiny chests and heaving G-strings: A night out with the Chippendales Sexualities 567-89.

Soothill, K. and Sanders, T. 2005, The geographical mobility, preferences and pleasures of prolific punters: a demonstration study of the activities of prostitutes' clients. Sociological Research Online 12.

Svanstrom, Y. 2000, Policing Public Women: the Regulation of Prostitution in Stockholm 1812-1880. Stockholm, Atlas Akademi.

Symanksi, R. 1974 Prostitution in Nevada. Annals of the Association of. American Geographers, 64, 357-377

Symanski, R. 1981, The immoral landscape. Toronto, Butterworths.

Thomas, J.A. 2000 Gay male video pornography: past, present and future. In: Weitzer, R. (Ed.) Sex for sale, prostitution, pornography and the sex industry. London, Routledge, pp. 79-92

Verbraeck, H. 1990, The German Bridge: a street hookers' strip in the Amsterdam Red Light District. In Lambert, Y. (ed) The Collection and interpretation of data from hidden populations, Rockville, US Dept of Health, pp. 56-67.

Visser, J. 1998, Selling private sex in public spaces: street sex work in the Netherlands. Paper presented at 'Perspectives on female prostitution conference, Liverpool Hope University.

Wagenaar, H. 2006, Democracy and prostitution: deliberating the legalization of brothels in the Netherlands. Adminstration and Society 38, 198-225.

Weitzer, R. 2005, New Directions in Research on Prostitution. Crime, Law, and Social Change 43, 29-45.

West, D.J. and de Villiers, B. 1992 Male prostitution - gay sex services in London London: Duckworth Press.

Whowell, M. 2006 Sexual identity in the city: male sex work in Manchester Paper given at the Royal Geographical Society with the Institute of British Geographers, annual conference, London.

Whowell, M. 2008 Canal Street? Exploring the performance and regulation of 
male sex work in Manchester Paper given at the Intersections of Gender, Class and Work, conference, Newcastle.

Wonders, R. and Michalowski ,R. 2001, Bodies, Borders, and Sex Tourism in a Globalized World: A Tale of Two Cities - Amsterdam and Havana. Social Problems 48, 545-571.

Zook, M.A. 2003, Underground globalization: Mapping the space of flows of the internet adult industry. Environment and Planning A 35, 1261-1280.

\section{LIST OF FIGURES}

Figure One: Spaces of sexual commerce across the twenty arondissement of central Paris (after Redoutey, 2005; Coulomb, 2007)

Figure Two: Spaces of commercial sex in central Amsterdam (source: authors' survey)

Figure Three: Model of urban prostitution markets (from Ashworth et al, 1988) 


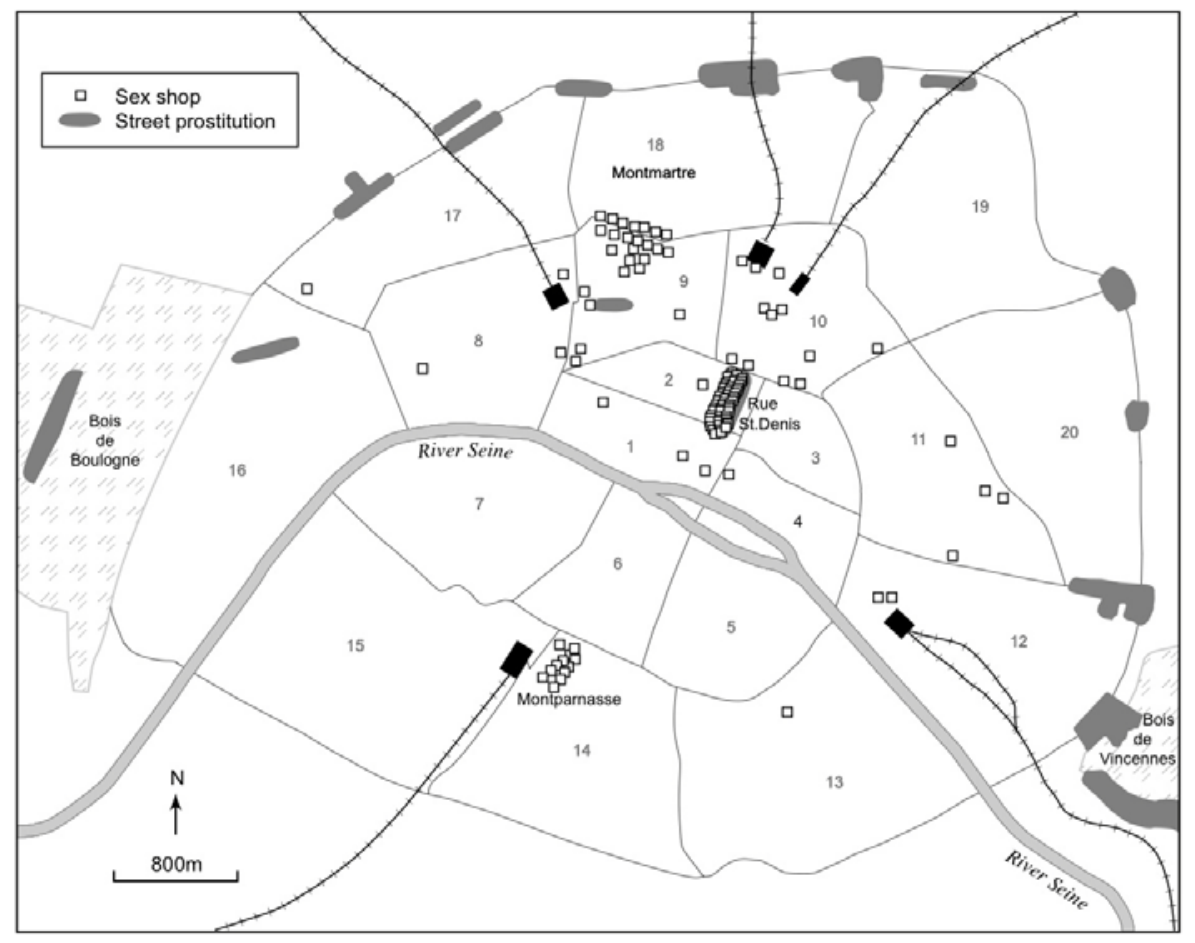




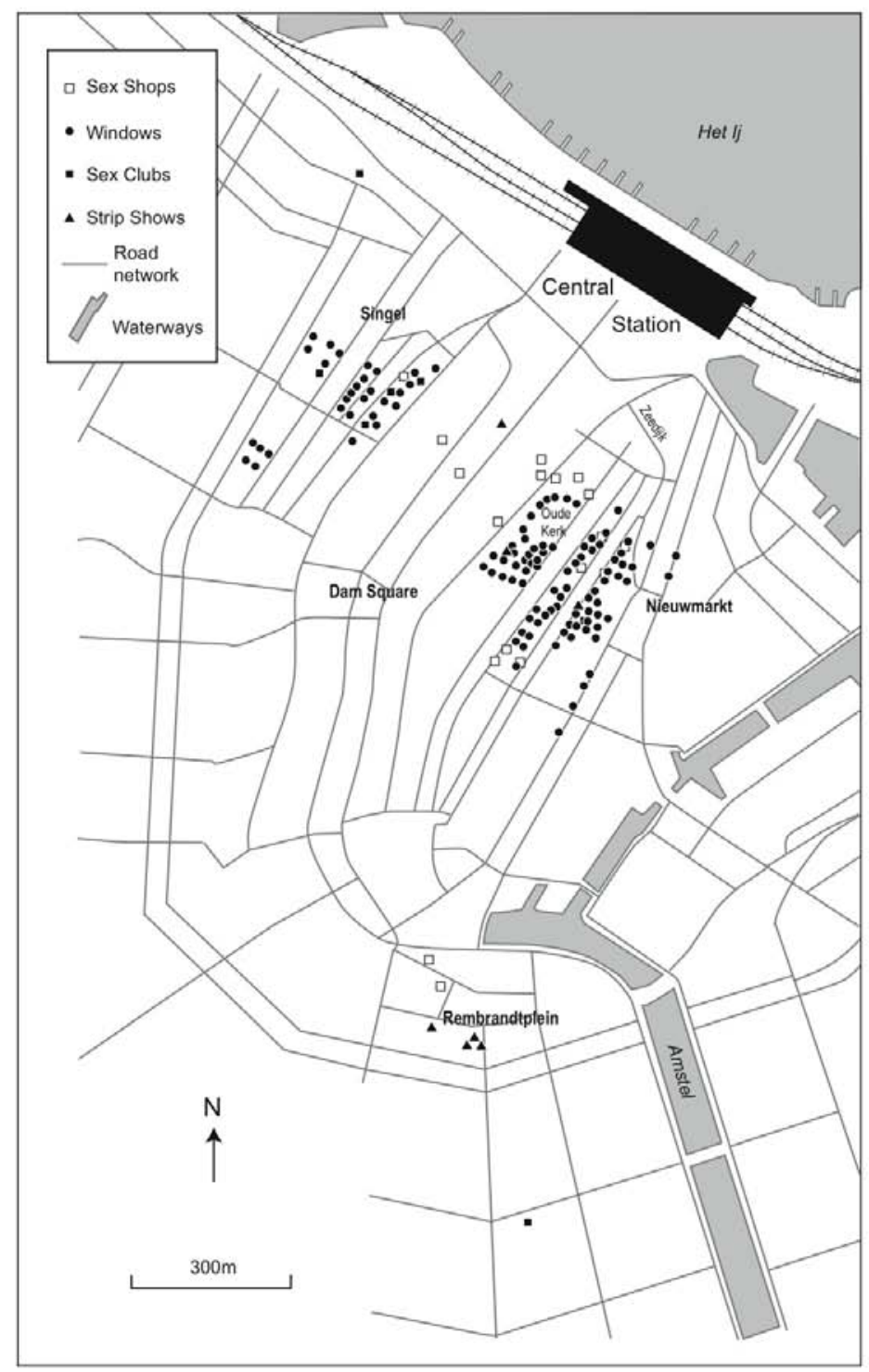




\begin{tabular}{|c|c|c|c|}
\hline & Local deprived & $\frac{\text { International }}{\underline{\text { wealthy }}}$ & Local wealthy \\
\hline LOCATION & $\begin{array}{c}\frac{\text { Multifunctional }}{1} \\
\frac{\text { Prostitution visibly }}{\text { coexisting with }} \\
\frac{\text { other land uses }}{1} \\
\frac{\text { Display (Blatant) }}{1} \\
\frac{\text { Transaction may }}{\text { be distant from }} \\
\frac{\text { display }}{1}\end{array}$ & $\begin{array}{c}\frac{\text { Monofunctional }}{1} \\
\frac{\text { Prostitution linked }}{\text { with other }} \\
\frac{\text { entertainment }}{1} \\
\frac{\text { Display (neon) }}{1} \\
\frac{\text { Transaction close }}{\text { to display }} \\
1\end{array}$ & $\begin{array}{c}\frac{\begin{array}{c}\text { Dispersed } \\
1 \\
\text { Prostitution }\end{array}}{\text { invisibly coexisting }} \\
\frac{\text { with other land }}{\frac{\text { uses }}{1}} \\
\frac{\text { Display (discrete) }}{1} \\
\frac{\text { Transaction }}{\frac{\text { dispersed }}{\text { (home/hotel) }}} \\
1\end{array}$ \\
\hline CONTROLS & $\begin{array}{c}1 \\
\text { Strong } \\
\end{array}$ & $\begin{array}{c}1 \\
\underline{\text { Weak }} \\
\begin{array}{c}\text { Accessibility } \\
\text { (macro-location) }\end{array} \\
\frac{\begin{array}{c}\text { Opportunity } \\
\text { (micro-location) }\end{array}}{\underline{\text { Constraint }}} \\
\text { (institutional) }\end{array}$ & $\begin{array}{c}\perp \\
\text { Minimal } \\
4\end{array}$ \\
\hline
\end{tabular}

Figure Three: Model of urban prostitution markets

(from Ashworth et al, 1988) 
